E3 Journal of Environmental Research and Management Vol. 7(1). pp. 025-028, August, 2016

Available online http://www.e3journals.org

ISSN 2141-7466 @ E3 Journals 2016

DOI : http://dx.doi.org/10.18685/EJERM(7)1 EJERM-16-013

Short communication

\title{
Screening and characterization of bacteria for decolorizing of Azo Dye
}

\author{
Churn-Hai Zhao*, Zhigang Liu, Hui dong LI, Zhenqing Li \\ Bin Zhou Binzhou Polytechnic, Key Laboratory of Agrobiotechnology of Binzhou 256603 China
}

Accepted 1 January, 2016

\begin{abstract}
Azo dye is a mainly pollution, the concentration of azo dye from the waste water is very high, it is difficult to decolour and degrade azo dye in nature. Bacteria have the ability to decolour and degrade, it can be biosorption the dye. Four strains were screened and identificated by the morphology of colonies and individual observation, Gram staining, flagella staining, spores formation experiment, physiological and biochemical reactions, these are belong to Bacillus, kurlhia, Klebsiella, the decolorization rate of four strains was more than $70 \%$.
\end{abstract}

Key words: screening; characterization; azo dye; decolorizing

\section{INTRODUCTION}

It had been reported on many papers about bacteria on biosorption, decoloration and degradation of dyes. Bacillus subtills could degradate azo dye. Now many decoloration bacteria were separated, which could use dyes as sole carbon sources. Some newly synthesized dyes developed to the direction of anti photolysis and oxidation resistance (Yang et al., 2002), which made the dye wastewater treatment more difficult. Decolorization bacteria were screened form the wastewater of printing and a dyeing factory and preliminary to identify them in our research (Khan et al., 2014)

The report on dye decolorization bacteria showed that the bacteria with a variety of dyes decolorization ability widely existed in nature, such as: Klebsiella, Rhodosiri11ium, Acetobacter, Pseudomonas, Enwinnia, Kurthian, Alcaligenes, Escherichi, Plesiamonas, Baci11cus ,Enterobacter, Serratia , Zoogloea, Xanthomonas et al., (Bazli et al., 2015) (Jaouadi et al., 2014).

\footnotetext{
*Corresponding authors: E-mail: shepherd@bzpt.edu.cn
}

\section{MATERIALS AND METHODS}

The source of water sample

A water sample was taken aeration tanks of printing and a dyeing factory in Bin Zhou City.

\section{Dyestuff}

Reactive red, reactive red $\mathrm{X}-3 \mathrm{~B}$, reactive brilliant orange $\mathrm{X}-\mathrm{GN}$, acid black NG, preparation of dye concentration of $10 \mathrm{~g} / \mathrm{L}$ solution, with $0.22 \mathrm{um}$ microporous membrane filtration, deposits.

\section{The main medium}

\section{Enrichment medium}

Peptone 2.0, beef extract 2.0, glucose 5.0, $\mathrm{KH}_{2} \mathrm{PO}_{4} 2.0$, $\mathrm{Na} \mathrm{HPO}{ }_{4} 12 \mathrm{H}_{2} \mathrm{O} 3.5, \mathrm{MgSO}_{4} 7 \mathrm{H}_{2} \mathrm{O}$ 0.1, dyestuff 0.01- 


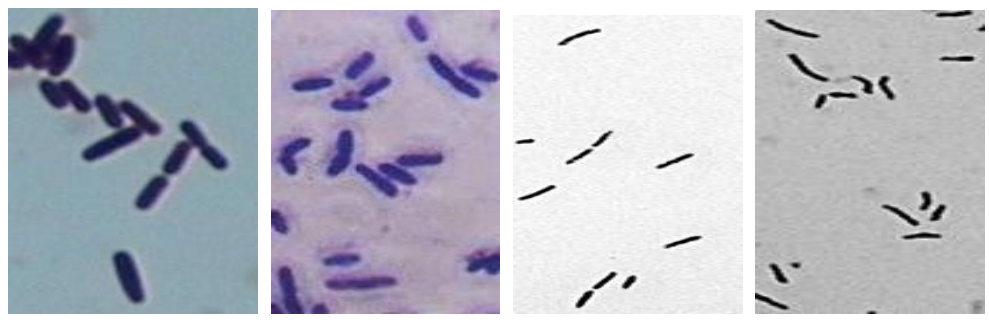

Figure1: The microscopic morphology of the four strains (from left to right ZB11, ZD17, ZG15, ZH23)

0.05, $1000 \mathrm{~mL}$ water, $\mathrm{pH} 7.2$.

\section{Beef-protein medium}

Beef extract 5.0 , peptone $10.0, \mathrm{NaCl} 5,1000 \mathrm{~mL}$ water, $\mathrm{pH} 7.2$.

\section{Screen dyestuff medium}

Addition a certain amount of dye to beef-protein media in the culture medium.

\section{Main instrument and equipment}

Spectrophotometer, centrifugal machine, incubator shaker.

\section{Water sample collection}

Water samples were collected in sterile glass bottles, which were from different parts of the aeration tank, inlet, outlet in sewage treatment plant of BinZhou city.

\section{Screening and culture}

$5 \mathrm{~mL}$ the waste water addition to containing $50 \mathrm{~mL}$ enriched culture fluid of $250 \mathrm{~mL}$ the triangle bottle, under the $37^{\circ} \mathrm{C} 120 \mathrm{rpm}$ oscillation culture, every five day the $10 \mathrm{~mL}$ culture solution was added to the $50 \mathrm{~mL}$ fresh medium(Strittmatter et al., 2015).

\section{Isolation and purification of resistant bacteria}

Culture solution to screening and culture was diluted, coating into containing the same concentration of dye, solid plate and $37^{\circ} \mathrm{Ccultivation} \mathrm{for} \mathrm{a} \mathrm{certain} \mathrm{period} \mathrm{of} \mathrm{time,}$ through comparison of colony morphology, texture, color, size, etc.,. Different strains were separated, purificated and inoculated in beef extract peptone slant culture medium (Linde et al., 2014).

\section{Screening of decolorizing bacteria}

The isolated strains inoculated in the liquid dye medium (dye concentration of $30 \mathrm{mg} / \mathrm{L}$, each test tube with $5 \mathrm{ml}$ medium, each strains inoculation three tubes), the static culture for a certain period of time, 8000rpm centrifugation for 30 minutes, the supernatant in the dye maximum absorption peak was measured the OD value with spectrophotometry, dye medium without inoculation bacteria as the control, calculating the decolorizing rate, showing the ability of decolorizing of dye(Singh et al., 2015).

decolorizing rate equation $=(A-B) / 100 \%$

$A$ : the OD value of without inoculation

$B$ : the OD value of with inoculation

\section{Identification of strains}

With enrichment culture and decolorizing ability test, efficient decolorizing strains were tested by the colony morphology and individual morphological observation, Gram staining, flagella staining, spores staining et al., , then doing physiological and biochemical experiments, identification the separation of decolorizing strains.

\section{RESULTS}

\section{Decolorization ability of different strains to the test}

With the enrichment and screening and the decolorizing test, four strains (Figure 1) have the high decolorizing ability, the result showed on the table1 As it could be seen from the table 1, the strains of bacteria of dye decolorizing ability were very strong, the decolorizing rate was more than $70 \%$. The decolorizing ability of different strains was different, and the decolorizing rate of ZG15 strains was more than $92 \%$.

\section{Preliminary identification of decolorizing strains}

With enrichment culture and decolorizing ability test, four strains of bacteria with strong decolorizing capacity were selected, with the method of the morphology of colony and individual observation, Gram staining, flagella staining, spores formation experiment, further physiological and biochemical reactions, including acid 
Table 1: Different strains decolorizing rate of different dyes

\begin{tabular}{ccc}
\hline Strain number & Dye name & The decolorizing rate \% \\
\hline ZB11 & Reactive red & 73 \\
ZD17 & Reactive red X-3B & 85 \\
ZG15 & Reactive brilliant orange X-GN & 92 \\
ZH23 & acid black NG & 85 \\
\hline
\end{tabular}

Table 2: The result of identification of the bacteria

\begin{tabular}{cc}
\hline Strain number & Genus \\
\hline ZB11 & Bacillus \\
ZD17 & Kurlhia \\
ZG15 & Bacillus \\
ZH23 & Klebsiella \\
\hline
\end{tabular}

Table 3: the colony morphology, individual character, physiological and biochemical traits of decolorizing bacterium

\begin{tabular}{|c|c|c|c|c|c|c|}
\hline $\begin{array}{l}\text { Strain } \\
\text { number }\end{array}$ & $\begin{array}{l}\text { Colony } \\
\text { morphology }\end{array}$ & Individual form & $\begin{array}{l}\text { Flagella } \\
\text { staining }\end{array}$ & $\begin{array}{l}\text { Gram } \\
\text { staining }\end{array}$ & $\begin{array}{l}\text { Spores } \\
\text { staining }\end{array}$ & $\begin{array}{l}\text { Acid fas } \\
\text { staining }\end{array}$ \\
\hline ZB11 & $\begin{array}{l}\text { round or irregular } \\
\text { uplift opaque }\end{array}$ & $\begin{array}{l}\text { straight rod } \\
0.5-1.0 \times 1.2-3.0 u m\end{array}$ & $\begin{array}{l}\text { peritrichous } \\
\text { flagella }\end{array}$ & + & + & 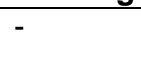 \\
\hline ZD17 & $\begin{array}{l}\text { Colony uplift, } \\
\text { irregular edge }\end{array}$ & $0.5-0.8 \times 3-4.5 u m$ & $\begin{array}{l}\text { peritrichous } \\
\text { flagella }\end{array}$ & + & - & - \\
\hline ZG15 & $\begin{array}{l}\text { round or irregular } \\
\text { uplift opaque }\end{array}$ & $\begin{array}{l}\text { straight rod } \\
0.5-1.0 \times 1.2-3.0 \text { um }\end{array}$ & $\begin{array}{l}\text { peritrichous } \\
\text { flagella }\end{array}$ & + & + & - \\
\hline $\mathrm{ZH} 23$ & $\begin{array}{l}\text { colony close to } \\
\text { circle, protruding } \\
\text { bright }\end{array}$ & $\begin{array}{l}\text { straight rod } \\
0.5-1.0 \times 0.5-5.0 u m\end{array}$ & without & - & - & - \\
\hline
\end{tabular}

Table 4: The physiological and biochemical traits of decolorizing bacterium

\begin{tabular}{ccccccc}
\hline $\begin{array}{c}\text { Strain } \\
\text { number }\end{array}$ & $\begin{array}{c}\text { oxidation glucose } \\
\text { fermentation }\end{array}$ & $\begin{array}{c}\text { contact enzyme } \\
\text { reaction }\end{array}$ & $\begin{array}{c}\text { oxidase } \\
\text { enzyme }\end{array}$ & $\begin{array}{c}\text { phenylalanine } \\
\text { deaminase }\end{array}$ & $\begin{array}{c}\text { potassium } \\
\text { cyanide (KCN) }\end{array}$ & $\begin{array}{c}\text { inositol } \\
\text { fermentation }\end{array}$ \\
\hline ZB11 & + & + & - & - & - & + \\
ZD17 & - & + & - & - & - & - \\
ZG15 & + & + & - & - & - & + \\
ZH23 & + & - & - & - & + & + \\
\hline
\end{tabular}

+Positive reaction, -Negative reaction

fast staining, oxidation of glucose fermentation, contact enzyme reaction, oxidase test, phenylalanine deaminase, potassium cyanide (KCN) experiment, inositol fermentation. The results showed that the four strains were classified into the following table 2 , table 3 , table 4 . Compared with the 16S rDNA (Figure 2). sequence of other bacterial strains in GenBank, the results of molecular biology identification validated the identification of the four strains of bacteria by morphological and physiological biochemical methods.

In the process of screening decolorizing bacteria, we found that the enrichment and cultivation of the dye gradient acclimation were very important. If there was not with the enrichment culture, because the decolorizing bacteria were low concentration, it was likely to difficult to be separated for the high concentration of non degrading bacteria (Rekik et al., 2015) (Silva et al., 2009).

\section{DISCUSSION}

The result showed that the concentration of dye in the nutrient fluid reduced, because of the treatment by the bacteria. During treatment there were some factors which could reduce the concentration of dye, one was the biosorption, the dye was adsorbed the cell surface of the bacteria, the dissolved dye in the waste water and nutrient fluid would reduce (Hajivandi et al., 2016). The second factor was the degradation of the bacteria, which could use the dye as the nutriment, sustaining the cell 


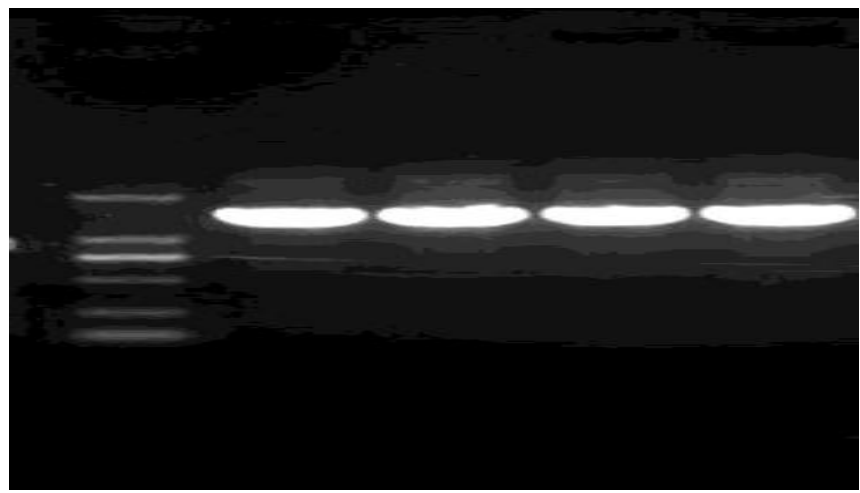

Figure 2: the16S rDNA of four strains (from left to right ZB11, ZD17, ZG15, ZH23)

growth (Huang et al., 2015). The biosorption of treatment of the bacteria was not complete to eliminate dye; the degradation of treatment of the bacteria was complete to eliminate dye (Kadam et al., 2015), to some extent the degradation method was better, but the degradation process may produce some small molecules, which may take new pollution and hazard, we should research on the degradation new products (Patil et al., 2016), it would help reduce the harm caused by the degradation new products.

\section{ACKNOWLEDGMENT}

This research is supported by Grant BS2012SW001 from National Natural Science Foundation of Shan Dong Province and the J14LE58 Project of Shandong Province Higher Educational Science and Technology Program from Shandong Provincial Education Department, 2014ZC0301 and 2011ZC0941from Bin Zhou Science and Technology Bureau, 2015 visiting scholar project from Shandong Provincial Education Department.

\section{REFERENCE}

ARS Silva, MJS Vaz, B Kwiatkowska, FX Malcata, ME Pintado, PR Moreira 25 (2009)., 25,78-S79 Isolation and screening of yeast strains possessing synthetic dye decolorizing activity New Biotechnology,

Abdollah H, Sima F, Bahman R, Samad A (2016). 7,71-76 Experimental data for synthesis of bi-metalized chitosan particle for attenuating of an azo dye from wastewater,

Ahmad BR, Jeong EH, Sung OH (2015). 50(8)1272-1276 Improved catalytic activities of a dye-decolorizing peroxidase (DyP) by overexpression of ALA and heme biosynthesis genes in Escherichia coli Process Biochemistry Archives of Biochemistry and Biophysics,
Avinash AK, Harshad SL, Dae SL, Sanjay P (2015). 1763846Govindwar Zinc chloride as a coagulant for textile dyes and treatment of generated dye sludge under the solid state fermentation: Hybrid treatment strategy Bioresource Technology,

Bassem J, Hatem R, Abdelmalek B, Nadia ZJ, Mouna B, Maher DL, Cristina C, Christiane L, Martin H, Angel TM, Francisco JRD (2014).103 28-37 Heterologous expression and physicochemical characterization of a fungal dye-decolorizing peroxidase from Auricularia auricula-judae Protein Expression and Purification,

Eric S, Kerstin S, Christiane L, René U, Martin H, Klaus P, Erik S, Dietmar AP (2015). 574(15):75-85 The toolbox of Auricularia auricula-judae dye-decolorizing peroxidase - Identification of three new potential substrate-interaction sites

Guangdao H, Wei W, Guoguang L (2015).157 (1) 297-302 Simultaneous chromate reduction and azo dye decolourization by Lactobacillus paracase CL1107 isolated from deep sea sediment Journal of Environmental Management.

Hatem R, Zaraî JN, Wacim B, Sidali K, Mouna B, Maher H, Amina B, Abdelmalek B, Naim S, Samir B, Bassem J (2015).73, 253-263 Characterization of a purified decolorizing detergent-stable peroxidase from Streptomyces griseosporeus SN9 International Journal of Biological Macromolecules,

Hmidi SK, Djamila F, Samir B (2014). (90)36-44 Production, purification, and characterization of a highly thermostable and humic acid biodegrading peroxidase from a decolorizing Streptomyces albidoflavus strain TN644 isolated from a Tunisian off-shore oil field International Biodeterioration \& Biodegradation, Volume 90.

Rahul S, Lindsay DE (2015),574(15)56-65 The multihued palette of dyedecolorizing peroxidases Archives of Biochemistry and Biophysics,

Swapnil MP, Vishal VC, Niraj RR, Rahul VK, Anuprita DW, Sanjay P (2016). 146,340-349 Govindwar Bioreactor with Ipomoea hederifolia adventitious roots and its endophyte Cladosporium cladosporioides for textile dye degradation Environmental Research.

Yang Dong hu Kan Zhenrong (2002).12(3):51-53 Isolation and characterization of bacteria for decolorizing of direct big red GBE Techniques and Equipment for Environmental Pollution Control.

Zeenat K, Kunal J, Ankita S, Datta M (2014). 94,167-175 Microaerophilic degradation of sulphonated azo dye - Reactive Red 195 by bacterial consortium AR1 through co-metabolism International Biodeterioration and Biodegradation. 